\title{
Wie is die sondaar? \\ Die beskouing van Karl Barth
}

F J van Zyl

Universiteit van Pretoria

\begin{abstract}
Who is the sinner? The view of Karl Barth

The previous article dealt with Barth's view of the knowledge and real essence of sin, while this one focus on his view of the human being as sinner. In accordance with his christological approach to all theological matters, Barth presents us with a description of the image and character of the sinner as mirrored by the obedient suffering and death of Jesus Christ on the cross in the place of all sinners of all times - past, present and future. The price that God paid in surrendering his only Son to such suffering, indicates the enormous guilt and baseness of every sinner. Every human being is utterly insolvent and can only be delivered from sin through God's graceful remission of sin.
\end{abstract}

\section{WIE IS DIE SONDAAR?}

Die antwoord op hierdie vraag sal drieledig wees. Voordat die antwoord op hierdie vraag ter sprake kom, moet egter eers enkele vooropmerkings gemaak word.

In die vorige gedeelte is die vraag beantwoord wat sonde is. Hier moet nou 'n antwoord gegee word op die vraag wie en wat die mens is wat sonde doen, wie en wat die karakter is van die mens-van-sonde. Ook hier word die antwoord gegee met die oog op Christus gerig. Volgens die leer oor Christus het dit in Hom gebeur en in Sy opwekking uit die dood bekend, waar en duidelik geword dat God, die Heer, vir ons, tot versoening van die wêreld met Hom, 'n dienskneg geword het, Homself verneder het. Vanuit hierdie christologiese kennis is die antwoord op die gestelde vraag, dat die mens-van-sonde die gevalle mens is, die mens wat daarheen geval het waar God, wat nie kan val nie, Hom in Jesus Christus verneder het ter wille van hom. Hy is die mens wat juis daar onder bestaan waar God hom in Jesus Christus opgesoek het en Hom as synsgelyke naas hom gestel het. Hy is presies dit wat Jesus Christus geword het om sy Heiland, Helper en Redder te wees: 'n kneg, 'n slaaf, maar nou nie in die vryheid van God nie, maar as 'n arme gevangene, nie in die heerlikheid waarin God was nie, maar in nood sonder meer, in grenselose skande. Sonder dat dit uitgespreek is, omvat hierdie antwoord minstens drie aspekte van die mens se val wat later uitvoeriger ter sprake sal kom. 
Die mens se val kom ooreen met sy hoogmoed wat ons as wese van die sonde aangetoon het. Volgens die spreekwoord kom hoogmeod voor die val, maar hier kom die mens in sy hoogmoed tot val. Hy val terwyl hy hom verhoog tot waartoe hy hom nie behoort te verhoog nie. Hy is besig om te sterwe omdat hy self vir hom 'n lewe wou neem, waarin hy, as hy dit wou ontvang, in vrede sou kon lewe.

Ook wat die kennis van die mens-van-sonde betref, mag 'n mens jou nie los van die openbaring in die Woord van God probeer verstaan nie. Soos niemand uit homself kan sien en erken dat hy in hoogmoed gesondig het en voortdurend sondig, so kan niemand uit homself sien en verstaan dat hy werklik geval het en nou daar onder as slaaf leef nie. Vanuit 'n mens se eie ervaring en kennis van lewensdieptes, sal wat die Bybel van jou val sê, altyd as te verskriklik en oordrewe beskou word. Die selfkennis van die mens waardeur hy homself as mens-van-sonde, as gevallene erken, kan alleen dié wees van iemand wat God se Woord hoor en glo, wat God se oordeel oor hom sien, erken en aanneem, wat homself in die lig van hierdie oordeel sien en verstaan. Alleen 'n mens wat die lewende stem van die evangelie verneem, kan hom só sien en verstaan. Hierdie evangelie is immers die evangelie omtrent die Heer wat ook ter wille van hom Homself verneder het en juis in sy plek dienskneg geword het. Wie hierdie lewende stem van die evangelie verneem, en hy alleen, ontvang die antwoord op die vraag wie hy werklik is. Hieraan moet alles ook gemeet word wat van die mens as sondaar gesê word.

'n Volgende vooropmerking oor die mens se val moet gemaak word. Eerstens ' $n$ beperkende. Hoe die gevallenheid van die mens ook beskryf mag word, kan en mag nie gesê word dat hy vir God verval, kwyt, verlore geraak het nie. Dis waar dat die mens se val dit alles beteken, dat daar 'n kloof, 'n leë ruimte van die Nietige in sy bestaan en midde in die goed geskape wêreld van God ontstaan het, tot Sy oneer en leedwese. God se positiewe wil het met die Nietige egter niks te doen nie. Dis waar dat die mens as't ware die rand van hierdie afgrond as gevalle mens geword het en dat hy die afskuwelike werklikheid van hierdie chaos duidelik en smartelik genoeg toon. Maar al is sy bestaan op hierdie rand van die afgrond 'n werklikheid, beteken dit nie dat hy uit God se positiewe wil geval het en vir God nie meer bestaan nie. Van die mens se kant gesien, kan hy wel Godloos word, maar nie van God se kant nie, God wat hom geskep en aan hom bestaan gegee het. (In geleerde taal word gesê dat die mens relatief Godloos kan word, maar nie ontologies nie) Dis egter erg genoeg dat hy dit wel relatief kan word. ' $n$ Mens kan jou nie werklik van God onttrek nie. My Godloosheid kan God nie mensloos makk nie. God hou nie op om Skepper, God, Verbondsheer van die gevalle mens te wees nie. In sy val bly die mens nog God se skepsel en verbondsgenoot. Soos hy homself nie kon skep nie, so kan hy hom ook nie omskep nie, nie tot die goeie nie, maar ook nie tot die 
bose nie. Hy kan hom nie in 'n ander wese verander nie en soos hy is kan hy hom ook nie tot niet maak nie. En soos hy nie die verbond aangegaan en gefunder het nie, kan hy dit ook nie ophef nie. 'n Mens kan aan die mens alleen 'n absolute Godloosheid toeskryf, as ons uitgangspunt prysgegee word, naamlik dat die mens alleen in wat met Jesus Christus gebeur het, geken kan word. Die mens het nie dieper geval as tot daar waar God Homself in Jesus Christus verneder het nie. God het egter in Jesus Christus nie duiwels of nietig geword nie. Sy Woord het mens geword, het ons verdorwe wese deelagtig geword. Verdorwenheid beteken egter nie verandering van die mens in 'n heeltemal ander wese nie, want dan sou sy versoening ongegrond wees. Ook die verlore seun by die varke het hom nog altyd in dieselfde wêreld bevind waar sy vaderhuis vêr weg gestaan het. Deur sy val is God se verbond met die mens deur hom totaal en onherstelbaar verbreek, maar as God se almagtige genadewerk nie ongeldig gemaak nie, nie opgehef, nie uitgewis nie. God hou sy ewige verbond egter in stand, herstel en vernuwe dit terwyl Hy Hom tot die gevalle mens wend. God laat Hom deur die sonde nie van stryk bring om vir die mens ja te sê nie. Juis wanneer Hy hom met Homself versoen, doen Hy Sy oorspronklike ja tot die mens gestand. Dis ' $n$ ja van geweldige en grondige afwysing van die mens se sonde en gevalle bestaan, ' $n$ ja van Sy oordelende genade, ' $n$ ja van doodvonnis en sy voltrekking. Dit is en bly egter God se ja, Sy verbondswil wat deur die sonde en val van die mens nie ongedaan gemaak is nie. In die deurvoering van hierdie ja ly God deur die mens, met die mens en vir die mens, neem selfs die dood van die mens op Homself. Hy neem dit egter op Hom om dit te oorwin, om sterwend as mens eers eg te lewe as God. Om te sê dat die mens in sy val absoluut Godloos is, dat sondigheid sy wese is, dat hy die ewebeeld van die duiwel is, sou die bewering moet insluit dat die lewende God wat Hom aan die mens verbind het en een met hom geword het nie net gesterf het nie, maar tot die dood verdoem was. Maar die dood het oor Hom tog nie geheers nie, veeleer het Hy die dood oorwin terwyl Hy dit op Hom geneem het en in Sy Seun met ons en vir ons gesterwe het.

By alles wat in die beperkende voorpmerking gesê is, gaan dit werklik nie om 'n versagting nie, maar eerder om 'n verskerping van die kennis van die mens as sondaar. Dit is die verskriklike van die toestand waarin die sondaar hom bevind, dat hy geensins uit die gebied van die lewende God, Sy ja en Sy genadewil ontslaan is nie, nie uit die verhouding van Skepper tot skepsel nie, en nie uit God se verbond met hom nie. Hy 'kan' wel val en van God afvallig word. Maar soos Psalm 139 dit treffend beskrywe, kan hy God nie ontvlug nie. Dat God nog altyd vir die mens ja sê, beteken dat hy wat dit nie wil hoor en hom daaroor van harte wil verheug nie, hierdie ja dan as 'n vernietigende nee moet hoor. God kan sy ja ook as 'n nee laat hoor. Dat God se genade op 'n mens gerig word, beteken dat wie dit verag en 'n 
afkeer daaraan het en nie daarvan wil lewe nie, deur God se toorn en gerig getref sal word. As 'n mens God wat ons vriend is soos 'n vyand behandel, kry jy God dan ook as 'n vyand.

\section{HOE LYK DIE SONDAAR?}

Ons kom nou by die eintlike saak waar dit hier om gaan, naamlik hoe die mens lyk wanneer ons kyk in die spieël van die Seun van God se gehoorsaamheid. Dit gaan hier om die mens wat in sonde geval het, tot wie God Homself in Jesus Christus neergbuig het, naas hom gaan staan het en Hom solidêr en gelyk aan hom gemaak het. Die vraag is, watter las het God wat Hy nie hoef te gedra het nie, vrywillig op Hom geneem en dit oorwinnend gedra en van ons af weggedra? Ons verdorwenheid kan immers nie 'n ander, nie 'n grotere of 'n kleinere wees as dit waarvoor Jesus Christus, en tot beëindiging daarvan, aan die kruis gely en gesterf het nie. Die vraag is wat hierdie verdorwenheid is wat Jesus Christus, die lewende Woord van God tot ons gerig, vir ons aantoon.

* Hierdie vraag word met drie stellings beantwoord, waarvan die eerste soos volg lui: Omdat daardie Woord - naamlik Jesus Christus as lewende Woord van God - die Woord van Goddelike vergewing is wat tot die mens gespreek is, is daaroor beslis dat die verdorwenheid waaruit dit hom roep en ruk, daarin geleë is dat die mens 'n skuldenaar teenoor God is wat nie in staat is om te betaal nie; wat God net kan vergewe omdat $\mathrm{Hy}$ van hom geen vereffening verwag nie omdat God hom daartoe nie in staat ag nie, meer nog, omdat enige ander vereffening, behalwe God se vergewing, nie korrek sal wees nie. God vergewe nie ongegrond, sinloos, toevallig of lighartig nie, of alleen omdat die mens nie in staat is om te betaal nie. God vergewe voor alles en beslissend omdat dít alleen die verbroke reg en die versteurde orde vanweë die sonde en skuld van die mens kan beëindig en herstel. Van hieruit kan ons probeer oordeel hoe dit met die mens se skuld gesteld is.

Skuld is die te kort skiet teenoor 'n verbintenis en 'n verpligting waardeur 'n mens skade berokken aan die persoon teenoor wie jy 'n verpligting het deurdat die verhouding tot hom versteur geraak het. Die skuldenaar is die oorsaak van alles en is aanspreeklik vir die skade wat hy die ander een berokken het. Die sonde van die menslike hoogmoed in die verhouding tot God, is so 'n te kort skiet en as sodanig die mens se skuld. Hierdie sonde moes hy nie begaan het nie. Ons het reeds gesien dat dit geen sin en geen grond het nie. 'n Mens kan dit net vasstel dat die mens dit doen. Dis sy werk en hy is daarvoor aanspreeklik. Die deemoed van geloof en gehoorsaamheid wat van die mens as skepsel van God en Sy bondgenoot vereis word, bly agterweë, ook die vryheid en 
moontlikhede waartoe God hom bekwaam gemaak het. Daar ontstaan 'n vakuum in die bestaan van die mens wat deur God goed geskape is. Daardeur word God se plan deurkruis, Sy eer verminder. God het Hom te intiem met die mens verbind, dat hierdie nalatigheid van ons kant Hom nie sou bedroef en krenk nie. Die mens alleen is aanspreeklik daarvoor dat dit gebeur. Hy kom God te na, hy is vir God 'n versteurder. Hy is dan ook daarvoor aanspreeklik dat daar 'n vertroebeling en versteuring, immers 'n verduistering en verwarring ingetree het in die verhouding tussen hom en God. $\mathrm{Hy}$ is aanspreeklik daarvoor dat God vir hom nie meer kan wees wat Hy as Skepper en Heer vir Hom behoort te wees nie, dat God se ja vir hom nou verhul is in 'n nee, dat Sy liefde nou 'n verterende vuur van Sy toorn geword het. $\mathrm{Hy}$ is aanspreeklik daarvoor dat die kloof en die vakuum wat deur die Nietige ontstaan het, deurwerk en chaos bring in die hele goeie skepping van God. Omdat hy te kort geskiet het in sy verpligting teenoor God, het die mens hier sluise van chaos en verwarring oopgemaak. Dit dan is die mens se skuld in die algemeen beskrywe.

Maar die saak moet miskien ietwat noukeuriger bekyk word. Ons het immers die volgende vasgestel: omdat die reaksie van God tot beëindiging van die situasie wat deur die skuld van die mens ontstaan het daarin bestaan dat God vergewe, en omdat in die prysgawe van Sy Seun in ons plek, God Hom bekendgemaak het as die God wat ons ons sonde vergewe, is oor twee sake beslis: eerstens dat die mens 'n insolvente skuldenaar is wat sy skuld nie kan betaal nie, en tweedens dat vergewing die enigste voldoende, korrekte en effektiewe werk is waarin God se reaksie voltrek kan word en voltrek is. Deur God se vergiffenis word ons nalatigheid en agterstand teenoor Hom weer goed gemaak, die versteurde verhouding tussen Hom en ons weer herstel, die chaos teruggedwing en die kloof toegemaak. Die vraag is hoe die skuld van die mens verstaan moet word in die lig van die feit dat God hom juis só ontmoet, as die God wat al sy sonde vergewe.

Dis duidelik dat die God wat die skuldenaarmens ontmoet as die God wat sy sonde vergewe, die barmhartige en in Sy wese die genadige God is, almagtig en heilig, Skepper van hemel en aarde, Heer van Sy verbond met die mens. Dis hierdie God van Wie die Skrif getuig dat waar die sonde meer geword het, Sy genade nog oorvloediger geword het, (Rom 5:20) en dat in hierdie teenstelling tussen sonde en genade juis God se vergewing Sy yster septer, Sy wapen, Sy swaard van geregtigheid en vryspraak was. Hy wat só oordeel en regeer is God in Sy onveranderlike bestaan en wese, en niemand anders nie. Met hierdie bestaan en wese moet die wyse waarop die mens teenoor Hom in verpligting staan, ooreenkom. Aan Hom is die mens onderwerp, nie as geringe teenoor ie- 
mand wat hom ver oortref nie, nie as eindige teenoor die oneindige nie. Dit is ook waar, maar die verhouding tot God het ' $n$ ander inhoud. Die vryheid, oneindigheid en oortreffendheid van God wat die mens teenoor Hom onder 'n verpligting stel, is die vryheid, oneindigheid en superioriteit van God se genade wat op die mens gerig is. Die beperktheid, eindigheid en geringheid van die mens, en daarom sy onderworpenheid aan God, is die beperktheid, eindigheid en geringheid van dié mens wat hom onverdiend, sonder enige toedoen van sy kant, op onbegryplike wyse kan verheug daaroor dat hy voorwerp van die genadige toewending van God is. ' $n$ Mens is tot niks anders gebonde en verplig nie as om jou hierdie genadige toewending van God te laat welgeval en in die vryheid, vreugde en vryheid wat daarmee gepaardgaan en daarmee ooreenstem, te lewe en net dankbaar daarin te wees. Inderdaad, die juk is sag en die las is lig. (Matt 11:30) Hier word nie te veel gevra nie. Hier het God se eis deur en deur 'n karakter van vergunning, hier word nie iets ongewoons geëis nie, maar alleen dat 'n mens sal wees wat jy is, een wat deur God liefgehê word en dat jy uit eie beweging sal bely dat God Hom eerste tot jou gewend het uit vrye beweging. Hier kan daar ook geen verskrikking wees vir die hoë majesteit van God nie en dit het ook geen sin dat die mens hom van God sal onttrek omdat sy eie bestaan te veel verskil van die van God. Immers die betrekking tot hierdie hoë God moet jy inderdaad nie eers soek en skep nie, maar dit staan vir jou wyd oop en is deur die hoë God wat so oneindig veel van jou verskil self geskep. Waarlik, 'n mens het nie die minste grond of enige aanleiding om hoogmoedig te kan of te mag wees nie.

Juis daarin word en is 'n mens skuldig deurdat jy jou in hierdie verhouding tot God besondig, teenoor Hom te kort skiet, Sy eer verminder, Sy orde versteur. Dit maak 'n mens se hoogmoed ongerymd, onvergeeflik en gee dit 'n kenmerkende nietige karakter. Hieruit mag dit nou duidelik wees dat en waarom ek as mens-van-sonde, as ek my eenkeer só herken het, vir myself net kan skrik. Ek is soos iemand wat hom op 'n steil helling bevind en net lie ergste kan vrees. Van hieruit is dit duidelik dat die geringste gedagte aan en stap in die rigting van daardie hoogmoed, ' $n$ besondiging is wat nooit weer herstel kan word nie. En nou kla Gods Woord ons nie aan net oor hierdie of daardie enkelvoudige daad, woord of gedagte nie, maar beskuldig ons dat ons ons hele lewe op die basis van hoogmoed voer en ons van begin tot end uit hierdie bodem voed. Die Woord beskuldig ons dat ons oral en altyd daaraan skuldig is, dat ons op God se genade nie met ooreenstemmende dankbaarheid nie, maar in een of ander vorm met ons jammerlike hoogmoed antwoord Omdat die orde waarin ons staan, God se genadeordening is waarin daarvoor gesorg is dat daar vir 
geeneen van sulke hoogmoed-dade grond of aanleiding is nie, stel ons ons in die leegte en bodemlose wanneer ons hierdie orde deurbreek. As hierdie orde nie ook vir ons, ten spyte van ons oortreding, bestendig sou wees nie, en as dit nie ook vir ons deur God weer herstel en gehandhaaf sou word nie, sou ons net verlore kon wees.

Die omvang van hierdie menslike skuld moet nog nader beskou word. As 'n mens dit versmaai om God se geliefde te wees en om Hom as die genadige God te erken, dan stel jy jou onder God se gerig, onder die nee van God. As jy God se goeie wil teenoor jou teenspreek, moet jy dit as so 'n teëprater ook verdra dat God se wil jou nou ook teëspreek. Dit is die toorn van God. Dit is God se onwil teenoor alles wat Hy nie wil nie, nie wou nie en nooit sal wil nie. Dit is God se heerskappy aan Sy linkerkant. God word dan vir 'n mens 'n vyand, ontmoet jou in die vreemde gestalte van die toornende God.

Nou is dit ook duidelik waarom 'n mens self nie jou skuld kan vereffen nie, jou nie self uit die bedreigde gebied van verwerping kan verwyder nie, jou versoening met God op geen wyse kan verwerklik nie. Aan God se genade het die mens hom besondig, en omdat hy oor God se genade geen beskikking het nie, sal sy poging om homself te red net verdere vergroting van sy sonde van hoogmoed wees. God se genade is 'n vrye genade, daarom kan die mens geen aanspraak daarop maak nie, ook nie op die wyse van die betoning daarvan nie. As God 'n mens in oordeel en gerig genadig wil wees, kan jy hierdie bladsy nie wil omblaai nie, maar jy moet lees wat daar staan. Vir 'n mens bly net een ding oor, en dit is om die genade van God in oordeel en gerig gelowig te aanvaar. So alleen kan jy bid: vergeef ons ons skulde. Hierdie gebed is die erkenning dat 'n mens jou sonde self nie kan vergewe nie, vir jouself nie genadig kan wees nie, ook nie wanneer jy God daarby wil betrek nie. Dit sou maar net 'n vernuwing van eiemagtigheid beteken wat die eintlike rede vir ons skuldigheid voor God is.

En so het die einde van ons oorwegings ons weer teruggebring by die begin daarvan, na die weg en die werk van God, na Sy vergewing, Sy vryspraak. Dat dit Sy weg en werk is met die oog op die mens en sy skuld, laat sigbaar word hoe dit gesteld is met die menslike skuld, hoe swaar en groot dit is. Dit word daarin sigbaar, dat die voltrekking van die Goddelike toorn en gerig, dat die Goddelike vryspraak ten slotte juis daarin bestaan, dat Hy ons sonde in die oorgawe van Sy Seun vir ons, vry en onvoorwaardelik vergewe. Om te sondig beteken om dit te doen wat hierdie God alleen, net as Hy Hom as die genadige bewys en openbaar, goed kan maak. Só groot is die gewig van sonde. 
* Op die vraag na die menslike verdorwenheid, word soos volg met 'n tweede stelling gantwoord: omdat Jesus Christus vir elke mens in sy besondere bestaan en gesteldheid tot sy versoening gesterf het, is beslis dat die menslike verdorwenheid radikaal en totaal is. Dit beteken dat die sondige verandering in die diepte en die sentrum van die menslike bestaan, in die mens se hart plaasvind en dat die sondige verkeerdheid wat daaruit vloei oor sy totale wese strek, sonder dat een of ander van sy bepaaldhede uitgesluit is.

Die lewende Woord van God bied 'n mens nie 'n gedeeltelike onderrig en opdrag nie, maar verlig my en maak op myself geheel en al aanspraak. Want die inhoud van hierdie Woord, naamlik die versoening wat in Jesus Chjrsitus plaasvind, bestaan nie in ' $n$ gedeeltelike verandering en verbetering van ' $n$ mens se kennis en houding nie, maar sonder meer in 'n totale verandering van jou situasie, en 'n omkeer na God toe van wie jy vervreem het in jou hoogmoed. Dit is dus hyself, sy hart, en van hierdie middelpunt uit die hele mens wat in hierdie vervreemding van God betrokke is en in hierdie vervreemdheid moet bestaan. Dit is sy verdorwenheid waarin God hom aantref en ken, waarin $\mathrm{Hy}$ hom aanneem en aanspreek. ' $n$ Mens is wat jy doen en jy doen wat jy is. En daarom leef 'n mens in hierdie kringloop van doen en wees binne hierdie afwending en vervreemding van God, heen en weer, uit en in die sonde.

Soos ons reeds gesien het, hou die mens nie op om mens te wees nie, ondanks sy totale sondigheid. Sy natuur wat goed geskape is het hy nie ingeboed en in die plek daarvan 'n bose natuur gekry nie. Die Bybel kla die mens van kop tot tone aan, maar betwis nie sy volle en onveranderlike menswees nie, ook nie die besit en gebruik van sy Godgegewe bekwaamhede nie. Volgens Genesis 1:27 het God die mens geskep as Sy verteenwoordiger, as beeld van God het Hy die mens geskep, man en vrou het Hy hulle geskep. Barth reken, veral met die oog op die laaste gedeelte van hierdie Bybelvers, dat die ewebeeldlikheid van die mens tot God in medemenslikheid moet verstaan word. Daaruit konkludeer hy dat daar van 'n verlies van hierdie beeld geen sprake kan wees nie, want ook as sondaar is hy nog man met sy vrou en mens met sy medemens en omgekeerd. Ook uit die verbond kan hy nie tree nie, al sou hy dit wil doen en al verdien hy ook om daaruit gesit te word. Die erns van 'n sondige mens is baie erger as die verlies van of beskadiging van sy goeie natuur. Dit bestaan daarin dat hy in sy goeie natuur, en binne in die verbond met God, hom in diens van die kwaad stel en nou daarin moet lewe. Dit is die skreiende teenspraak, dat hy in die goeie en as die goeie, Godloos geword het en tot die niksheid verval het in sy hoogmoed. As God se uitverkore bondgenoot word hy nou bedreig deur Goddelike verwerping, met die ewige dood, met verlorenheid. In hierdie teenspraak is die mens onverontskuldigbaar, doen hy wat hy is en is hy wat hy doen. 
Van 'n oorblywende res of kern wat goed is, kan daar dan ook geen sprake wees nie. Die mens is nie 'n hoeveelheid teenoor sy sonde as 'n ander hoeveelheid nie. Die ontsaglike erns van die situasie bestaan daarin dat die een ganse mens wat God goed geskape het, lei en onderhou en regeer en wat vir hom dieselfde is soos die eerste dag, en wat nie ophou om hom as Sy bondgenoot te erken nie, dat juis hierdie mens wat deur God uitverkies en vol uitgerus het vir Sy diens, hom van God afkeer en nou is wat hy in hierdie vervreemding moet wees: verkeerd, skuldig, vyand van God, voorwerp van God se toorn omdat hy hom dit nie wou laat geval om voorwerp van Sy genade te wees nie. Hoe sou daar uit hierdie totale bepaling van die mens ' $n$ res uitgehaal kon word wat goed is? Wat as goed ter sprake sou kon kom, kan tog net die goeie en genadige wil van God wees wat in en oor die goeie natuur van die mens werksaam is: die mens se bestaan voor God as voorwerp van Sy genade ook in die gestalte van Sy oordeel. Wat 'n mens voor God is, is jy resloos, sonder 'n res, totaal en beslissend. Van 'n onaangeraakte goeie kern kan daar by die mens geen sprake wees nie. Die Woord van God kla die mens juis aan dat hy in sy diepste kern, sy hart sondig is. In sy sondige hoogmoed wil hy self God en Heer wees, self regter oor goed en kwaad en sy eie helper wees. In dit alles haat hy God en sy naaste.

Dit beteken dan kennelik dat daar wat die menslike oortreding en verderf betref, nie ' $n$ van te vore is waarin die mens geen oortreder en dus nie skuldig was nie. Hy leef, om saam met 'n groot geleerde te praat, uit 'n verkeerde prinsiep, vanuit die radikale kwaad, waarmee hy wel nie identies is nie, maar waarmee hy hom verbind en verbonde is. Hy oortree omdat hy altyd van die oortreding reeds kom, en reeds omdat hy bestaan hierdie oortreding begaan. Nooit was die mens nie hoogmoedig nie. Hy is dit in sy eie daad,in sy bestaan. Hy was dit altyd. Hy sondig nie net nie, maar hy is 'n sondaar. Die aanklag teen hom, wat sy oortredinge betref, mag diskussie en argumentasie uitlok, maar nie wat homself betref nie. Daarom het Jesus nie vir hom gesterf om hierdie of daardie sonde te verwyder nie, maar vir sy omkering tot God, om sy valse uitgangspunt te verwyder sodat hy nuut gebore mag word deur die Gees en uit 'n nuwe oorsprong en begin 'n nuwe mens kan word. As dit waar is, dan is dit ook waar dat die mens sonder Jesus altyd 'n onversoende mens was, oorspronklik en van die begin af vlees, sondig, die ou mens wat God en sy naaste altyd gehaat het en dus altyd 'n kind van die toorn is.

Aangesien dit so is, bestaan daar ook geen uitsondering, geen verskoonde gebied met betrekking tot die oortreding en verdorwenheid van die mens waar hy nie skuldig en verkeerd is nie. Teenoor God is hy in elke opsig verkeerd en 
het hy 'n agterstand. As subjek is hy geen goeie boom nie, daarom kan hy ook nie goeie vrugte dra nie. Omdat sy hoogmoed radikaal en prinsipieël is, is dit ook alles omvattend, en dra alles wat hy dink, sê en doen 'n sondige stempel. Omdat hy nie net gedeeltelik nie, maar geheel en al vlees is, dra al sy handelinge, gevoelens en uitinge 'n vleeslike karakter.

Daar is ook geen neutrale gebiede waar die mens in sy lewenshandelinge alleen en by homself, aan die ander kant van goed en kwaad, van gehoorsaamheid en ongehoorsaamheid staan nie. Altyd staan hy ook voor die aangesig van God en sy medemens in wat hy dink, sê en doen. Daar is geen gebied of tyd waarin God se genade en gebod nie tot hom gerig is nie, en geen gebied of uur sonder beslissings nie. Maar omdat die mens van nature boos en sondig is, is elke uur en gebied die van ongehoorsaamheid. Hoewel die gebod van God tot elke mens in 'n eie bepaalde gestalte en vorm telkens kom, sal die antwoord van almal nie gelykvormig wees nie en volgens menslike norme en maatstawwe net by benadering, en net onder die ernstigste voorbehoud as skuld en sonde veroordeel kan word. Nie 'n mens self nie, ook nie jou medemens nie, maar God alleen wat jou hart ken is immers jou aanklaer en regter. Omdat God se Woord elke mens aankla dat sy hart boos en vleeslik is, kan daar geen twyfel bestaan nie dat alle beslissinge van elke mens in alle gebiede en tye, die karakter van foutiewe beslissinge en valse antwoorde op die gebod van God sal hê sodat hy hom oor wat hy volbring nie sou kon beroem nie, maar eerder skaam. Ook wanneer die mens in sy eie oë en in die oë van ander wat hom volgens bepaalde norme beoordeel, in sy skik mag wees met prestasies in die verwerkliking van sy goeie natuur, is hy tog met alles wat hy is verkoop onder die sonde en staan sy goeie dade ook in diens van die kwaad.

Dit sou 'n groot vergissing wees om wat nou net vasgestel is as pessimistiese oordrywing te beskou. Een of ander tyd vra 'n mens jouself tog af: waar staan ek? Wie is ek? Hoe is dit gesteld met my hart? Daar is nog ander vrae: hoe was dit in een of ander tydstip of omstandigheid van my lewe gesteld met my verantwoordelikheid teenoor God en Sy gebod? Was die bewussyn van my verantwoordelikheid suiwer en eerlik? Hoe was dit gesteld met die erns waarmee ek probeer het om die wil van God te deurgrond, om te soek na wat vir God goed, aanneemlik en volmaak is (Rom 12:2)? Hoe was dit nog altyd gesteld met die beslistheid waarmee ek aggee op wat ek as reg erken het? Was my dade hiermee in ooreenstemming? Die moontlikheid om te ontken en dit te bestry dat die hele mens in al sy handelinge 'n sondaar is, en dit as oordrywing te bestempel, beteken net een ding; dat al die gestelde vrae nie geken, of in hulle volle erns nie erken word nie. Al die vrae moet ons hoor en verstaan as 
vrae wat ten slotte op die een en enige vraag neerkom: hoe staan ek voor God? As ' $n$ mens hierdie vraag in sy volle gewig verstaan, kan daar oor die stelling, dat die mens in sy geheel skuldig en sondig is, geen woordestryd bestaan nie. Dit word inderdaad anderkant die teenstelling tussen 'n ooroptimistiese en oorpessimistiese menslike selfbeoordeling beslis, naamlik wat God in die Woord van Sy genade Self vir ons te sê het.

Val die beslissing van daardie kant af, is dit ook 'n growwe vergissing om te reken dat die stelling omtrent ons totale sondigheid hom daartoe leen om ons konkrete menslike sondekennis, die bewussyn van ons konkrete verantwoordelikheid, en die moed van konkrete teenstand teen die kwaad te verlam en selfs op te hef ten gunste van 'n onvrugbare afsydigheid en gelatenheid teenoor enige hoop op 'n menslike bestaan wat vry is van sonde en skuld. Juis daarom kan dit nie klop nie, omdat hierdie standpunt net bedink en uitgespreek kan word in die konkrete kennis en verantwoordelikheid van 'n mens wat die Woord van God se genade en Sy eis gehoor het, net as erkenning van die Goddelike oordeel en gerig wat hom konkreet aangaan. Juis omdat hy dit erken, kan dit nie 'n berustende stelling wees nie, maar dit word 'n konkrete roep: verlos ons van die Bose. Die mens wat só roep, kan hom nie tevredestel met sy verderf nie, maar hy sien uit na die totale verwydering daarvan. Meer nog, as konkrete erkenning van God se oordeel en gerig, is daardie stelling reeds weer die konkrete belydenis van Hom Wie se daad ook daar nie tevergeefs was waar alles wat ons doen ongetwyfeld tevergeefs is, ook in die beste lewe. Dis 'n belydenis van Hom wat daar help waar alle menslike selfhulp die kwaad net kan bevestig en vergroot. Omdat hierdie erkenning en belydenis in Hom sy grond het, kan dit nie 'n vryblywende, berustende, hooplose en passiewe belydenis wees nie. Wie tot hierdie belydenis in staat is en daartoe gewillig is, hou aan God se barmhartigheid vas, stel homself in die ongelyk en beskou homself onmagtig teenoor hierdie groter mag. Omdat hy hierdie oorweldigende heerlikheid voor oë het, kan en mag hy nie op enigiets van homself roem nie. Maar terwyl en omdat hy alleen op die Here wag sal hy met arendsvlerke vlieg en met 'n veerkrag waarvan hulle wat die stelling kritiseer dat die mens totaal en prinsipiëel sondig en skuldig is, gewoonlik nie die minste begrip het nie.

* Die derde stelling as antwoord op die vraag na die mens se verdorwenheid, is ontleen aan Rom 11:32: aangesien God Hom in die oorgawe van Jesus Christus oor alle mense wou erbarm en erbarm het, is daaroor beslis dat Hy hulle almal vantevore onder die 'ongehoorsaamheid ingesluit' het. 'Ingesluit' beteken hier om hulle onder 'n geldige, ontwyfelbare, onaanvegbare en onomstootlike oordeel en vonnis te stel, met al die gevolge wat daaruit mag voortvloei. God se 
erbarming stem ooreen met Sy insluiting. Hulle oor wie God Hom wou erbarm is dieselfde as die wat $\mathrm{Hy}$ vantevore ingesluit het onder die oordeel en vonnis. Dit word van alle mense gesê.

Dit gaan hier om twee groot samehange waarin alle mense volgens God se wil en bepaling staan. Die een omvat almal vorentoe in hulle toekomstige bestaan, hulle tot wie God se erbarming toegewnd is deurdat Sy Seun vir hulle in die vreemde gegaan het. Die ander omvat hulle almal weer terugwaarts, in hulle bestaan wat gewees het. Dit is die samehang van 'insluiting', die wat God met die oog daarop saamgevoeg het, hulle aansien, aanspreek en behandel, dat hulle almal in hulle hoogmoed hulle eie weg gegaan het waarop hulle almal moes val. Dis die samehang waarin almal volgens die oordeel van God se Woord tot die stand van ongehoorsaamheid behoort. Dis hulle wat met hulle bestaan in die vreemde deur God in Sy Seun opgesoek is om hulle tot die vaderland terug te roep en terug te bring. In die hede van alle mense ontmoet en kruis albei samehange en eenhede mekaar, val die beslissing vir hulle almal in die evangelie van Jesus Christus, wat aan hulle geopenbaar en verkondig en deur hulle gehoor is, die evangelie wat deur hulle geglo en verstaan is, of nie geglo en nie begryp is nie. Só klink die woord van die apostel Paulus, en só klink die belydenis van die kerk, voorlopig in die plek van die hele wêreld: $\mathrm{Hy}$ (die Vader) het ons uit die mag van die duisternis weggeruk en ons onder die heerskappy gestel van Sy Seun wat Hy liefhet (Kol 1:13). Die 'mag van die duisternis' is presies dieselfde as om ingesluit te wees onder die ongehoorsaamheid, die samehang waarin God se reguerdige oordeel almal tevore saamgevoeg het. Wie in die ryk van Christus sy toekoms het, het in die magsgebied van die duisternis sy verlede. Hierop moet nog verder uitgebrei word.

Alles wat tot hiertoe oor die mens se sonde, sy hoogmoed en val gesê is, het oor die mens se verlede gehandel, oor sy bestaan wat agter hom lê. In die opstan-ding van Jesus Christus uit die dood onthul God vir ons as't ware agterna wie in Sy dood oorwin en vernietig is. Dis die mens-van-sonde. Daar is getrag om die mens van ongehoorsaamheid daar te herken waar hy vernietig is, naamlik in die spieël van gehoorsaamheid van die Seun van God. Die beslissende wat van hierdie mens gesê kan word, is dat hy tot niet gemaak is, jy behoort tot die verlede en het nie meer ' $n$ toekoms nie. As ons nog altyd daardie mens is, hom weer opnuut is, en as ons dit weer sal wees, dan is die beslissende wat van ons gesê kan word, dat ons dit net as reeds tot niet gemakte, in bespotlike voortelling van ons eie verlede as ons eie spookverskyning, kan en sal wees. Dis tog ' $n$ teenstrydigheid dat die mens-van-sonde wat aan die kruis van Golgota doodgemaak is en gesterwe het, nog 'n lewende kan wees. Paulus motiveer die 
onmoontlikheid om nog in die sonde te volhard deur verwysing na Rom 6:9: 'Ons weet dat Christus wat uit die dood opgewek is, nie weer kan sterwe nie; die dood het nie meer mag oor Hom nie. Hy het gesterwe en is eens en vir altyd vir die sonde dood. Nou lewe Hy en Hy lewe vir God. Julle moet dus altyd onthou dat julle vir die sonde dood is maar vir God lewe, omdat julle een is met Christus Jesus'. Daar bestaan geen vryheid meer om sonde weer opnuut te doen nie. Die magsgebeid van die duisternis lê agter ons. Ons almal is uit daardie gevangenis vrygelaat.

Om hierdie gevangenis waar ons ingesluit was goed te ken, is 'n ersntige saak, want dit sou nie moontlik gewees het om daarvandaan met dankbare vasberadenheid vorentoe te kyk en te gaan nie sonder kennis van wat agter ons lê nie. As ons nogeens na Rom 11:32 luister, hoor ons daar dat almal in die ongehoorsaamheid ingesluit is. Die radikaliteit en totaliteit van sonde en skuld waaroor in die vorige hoofgedeelte gehandel is, stem ooreen met die universaliteit daarvan. Hoewel die Bybel nie die woord 'mensheid' ken nie, kan die woord 'almal' met reg as die ekwivalent, die gelykwaardige begrip daarvoor aanvaar word. Nie net enkele mense nie, maar almal, die hele mensheid is sondig en doen sonde. 'Almal het gesondig en is ver van God af' (Rom 3:23). Die oordeel en gerig van God tref altyd hierdie een en hierdie almal. Die enkeling is deel van die hele gemeenskap. As 'n mens in die lig van God se genadewoord jou eie sonde mag erken, dan ken jy in jouself die hele mensheid as sondige en skuldige mense voor God. Wat op Golgota gebeur het, het nie net vir my plaasgevind nie, maar vir ons. Daarom bid ons ook: Ons Vader; vergeef ons ons oortredings. Nadat Israel en die volke na die dood van Jesus Christus een volk geword het, het hierdie 'ons' grensloos geword. Net van die evangelie af sou die gedagte van 'n mensheid as christelike begrip aanvaar kon word en wel in dié sin dat dit die geheel en somtotaal van alle mense is tot wie God se genade gerig is, met die oog daarop dat hulle almal voor Hom sondig en skuldig is.

Soos die Bybel nie die begrip 'mensheid' ken nie, so ook nie die begrip 'geskiedenis' nie. Maar die woord 'almal' laat ook dink aan wat ons met die begrip 'geskiedenis' bedoel.

Die Bybel is die geskiedenisboek by uitnemendheid as getuienis van 'n besondere geskiedenis, naamlik die getuienis van God se teenwoordigheid, handeling en openbaring as 'n suiwer aards-menslike geskiedenis. In hierdie geskiedenis gaan dit om die wil en woord en werk van God onder die mense. In hierdie geskiedenis gaan dit nie om die oorspronge, samehange, verwikkelinge, saamvoegings en skeidings, doelstellings en nuwe beginne van menslike wil en 
onderneming nie, nie om hulle motiewe, praktyke en toekomsverwagtings nie. In die Bybel gaan dit om hierdie geskiedenis net sover as wat dit in die ligbaan van daardie ander geskiedenis sigbaar word. Kenmerkend van hierdie menslike geskiedenis is dat dit losgemaak is van die wil en woord en werk van God en as sodanig reeds gegrond is in 'n verkeerde, sondige menslike denke, 'n uitvinding van die menslike hoogmeod. So 'n geskiedenis is geen illusie nie want dit bestaan inderdaad in die wêreld. Kennis van menslike sonde en skuld in die lig van die Woord van genade impliseer dat hierdie geskiedenis wat in menslike hoogmoed gegrond is, onder die gerig van God verloop. Die wêreldgeskiedenis is ingesluit in die ongehoorsaamheid. Dit beteken nie dat dit aan die regering van God ontruk is en onder die heerskappy van 'n nooodlot of die duiwel gestel is nie. Die Goddelike regering van die wêreldgekiedenis het ook nie opgehou om die regering te wees van Hom wat vir die mense goed was, is en sal wees nie. Die geskiedenis van die wêreld wat deur God in Jesus Christus geskep is, en op Hom, Jesus Christus, gerig is, kan met die val van die mens nie ophou om in Hom sy sentrum en doel te hê nie. Van hierdie sentrum af kan God tot die verandering en verkeerdheid nie ja sê nie, maar net nee. Elkeen wat van hierdie sentrum af die genadewoord hoor, kan nie makk of hy die nee nie hoor nie, kan dit nie verswak nie, nie anders verklaar nie, nie vergeet nie. Diep verborge onder hierdie nee is God se ja verskuil vir hierdie arme en verkeerde mens wat as subjek van hierdie geskiedenis handel en ly. Dis egter ook Sy nee tot die verkeerdheid van hierdie wêreldgeskiedenis.

Ons mag nie vergeet nie dat die mens sy goeie natuur met al sy bekwaamhede nie kwytgeraak het deur sy eie verandering en deur die gerig van God wat oor hom uitgespreek is nie. Verstommende planne, ontsagwekkende inspanning en bewonderingswaardige resultate en prestasies, meesterwerke van bekwaamheid en deug is binne hierdie insluiting in die ongehoorsaamheid moontlik en werklik. Al steek dit af by baie van ons minder glansende, gevaarlike en verderflike menslike handelinge, staan dit tog op dieselfde noemer van sonde, ongehoorsaamheid en hoogmoed en daarom onder die gerig van God. Dis in elk geval dwaasheid om uit vooruitgang op een bepaalde gebied, byvoorbeeld die tegniek, te konkludeer dat dit ook vooruitgang van die mensheid beteken. Eintlik is die mens se stilstand, miskien sy agteruitgang, kenmerkender as sy vooruitgang. Sy lewe vertoon 'n verrassende eentonigheid, die eentonigheid van sy sondige hoogmoed waarin hy van vroeg af vir homself en sy naarte 'n lewe van leed gelei het, en so sal dit wees tot die einde toe. Dit is die betekenis daarvan dat die wêreldgeskiedenis in die ongehoorsaamheid ingesluit is. 
Die mens en die wêreldgeskiedenis word in die Bybel onder die naam 'Adam' gestel. Adam beteken eenvoudig, mens. As draer van hierdie eienaam, wat die bestaan en wese tipeer van alle skepsele wat aan hom gelyk is, verskyn hy in die Genesisverhaal as die mens wat sy bestaan direk aan die Skepperwil, woord en -werk van God dank en wat as sodanig die eerste, die oermens is. Adam as die oortreder is die opskrif wat God bo die wèreldgeskiedenis gestel het. Sy naam is die verklaring van die hoofsom van die geskiedenis van die mensheid wat God prysgegee het vanweë die hoogmoed van die mens. Dis die verklaring van die sin - onsin - van hierdie wêreldgeskiedenis. Dit is Adamsgeskiedenis, want dit begin met sy geskiedenis en stem in sy verloop altyd weer ooreen met sy geskiedenis, in ontelbare variasies herhaal, eindelose herhaling van 'n stukkie van Eden.

Daar was nooit 'n goue eeu nie. Dis sinneloos om na so iets terug te verlang. Die oermens was tegelyk die oersondaar. Volgens die Ou Testament het die wêreldgeskiedenis só begin, daarom stel hy Adam boaan die geskiedenis van mensewil en -handeling. Ook hierna sal die Ou Testament vertel dat alles altyd so begin: onmiddellik na die ervaring van die goedheid van God, begin dit met gedagtes, woorde en werke, domheid en boosheid van die mens. Dis die struktuur van die handeling van die Here met Israel. Dis die struktuur van die geskiedenis van God met alle volke. God ken alle mense en groepe van mense. 'Van die hemel af kyk die Here die mense deur om te sien of daar én verstandig is, én wat na die wil van God vra. Almal het afgedwaal, die laaste een het ontaard; daar is niemand wat goed doen nie, selfs nie één nie (Ps 14:2, 33). In die kennis van God wat die mense van alle tye deursien, is hulle almal weer en nogeens Adam, wat doen wat hy eerste gedoen het.

Wie is Adam? Die groot naamlose wat die stamvader van die menslike geslag was? Daar bestaan geen twyfel dat die Bybelse oorlewering hom ook só wou sien en bestempel. Maar Bybelse interesse in hom is meer geleë in wat hy gedoen het. Dus 'n besonder belaste sondaar? Maar sy oortreding was immers in vergelyking met ander van wie die Ou Testament berig, sommiges baie heilige mense, so gering dat ' $n$ mens huiwerig is om hom as eerste onder gelykes aan te dui. In onopvallende vorm van die beginner, doen almal wat na hom gekom het dieselfde, wat of dit nou swaarder of ligter, sigbaarder of onsigbaarder ook ons vergryp is. Hy was heeltemal alledaags wat ons almal is, 'n mens-vansonde. In sover hy die beginner was, kan hy ook eerste onder gelykes genoem word. Hy het ons dit egter nie as erfenis nagelaat dat ons soos hy moet wees nie. Hy het ons nie vergiftig en sieklik gemaak nie. Wat na hom gedoen word, word ook nie gedoen as noodlottige navolging van 'n nonweerstaanbare nade- 
lige voorbeeld wat sy daad aan ' $n$ afstammeling gestel het nie. Niemand hoef weer en nog eens Adam te wees nie. Ons is dit almal in eie verantwoordelikheid en uit vrye wil. Hoewel dit aan ons s'n gelyk is, is Adam se skuld nie vir ons 'n verskoning nie en ons s'n nie 'n verskoning vir hom nie. Hy en ons word deur die Woord en oordeel van God op gelyke wyse onmiddelbaar getref. Al verskil is dat dieselfde wat ons almal is en doen, hy was en gedoen het by die ingangspoort van die geskiedenis en dus eerste deur God se Woord en oordeel getref is, as eksemplaar van almal wat na hom gekom het. Wie is hierdie ander en in watter verhouding staan hulle tot Adam, die wat na hom kom? Dat hulle fisiese afstammelinge van hom was het die Bybel seker ook in die oog gehad. Hoe kom dit dat hulle ook in die daad van sy oortreding aan hom gelyk geword het? As ons die sonde, by ons en Adam as 'n menslike beslissing en daad aanvaar, en dat die sondigheid nie as 'n erfenis in die opvolging van geslagte gesien kan word nie, bly niks anders oor as om te sê dat die ander wat na Adam kom, hulle is wat in sy persoon en daad verteenwoordig is. Dis hulle wie se wil korrek vooruit as verkeerde wil geïnterpreteer en tot uitdrukking gebring is. Anders gesê, hulle is diegene wie se vrye wil, doen en late, wie se realisering, verwerkliking van hulle menslike natuur, wat self goed is, juis volgens die reël verloop, juis die verkeerde orde volg wat volgens die profetiese getuienis, netsoos by die begin van die groot wêreldgeskiedenis, reeds in die persoon en daad van Adam, kenmerkend vir die persone en dade van almal na hom sigbaar geword het. In hom moet ons onsself, die mensheid en wêreldgeskiedenis herken. Adam is nie die noodlot wat deur God oor ons beskik word nie. Adam is die waarheid oor ons, deur God geken en gesê. Die samehang tussen ons en hom kan nie in wêreldse feitelikhede gefundeer of aangetoon word nie, maar God stel dit vas. God se Woord gee die mens hierdie naam, en die wêreldgeskiedenis hierdie opskrif. God se Woord veroordeel sy en ons ongehoorsaamheid. God se Woord verbied ons om van 'n eens gewese goue eeu, of van 'n werklike vooruitgang in die Adamitiese mensheid en geskiedenis, of van 'n toekomstige wêreldgeskiedkundige toekoms te droom, en om ons hoop op enigiets anders te stel as op die versoening wat in Jesus Christus plaasgevind het.

Ons het gehoor dat die sonde van Adam die opskrif is bokant die bestaan van alle mense, dat God in sy persoon en daad die ganse mensheid, die totale wêreldgeskiedenis, ons almal beoordeel en veroordeel het: ingesluit onder die ongehoorsaamheid. Die vraag is nou waarom en in hoeverre ons dit as Woord van God moet hoor en respekteer. 'n Blik kortliks op Romeine 5:12-21 mag vir ons 'n antwoord gee. Wie is Adam vir Paulus? Volgens vers 12 was hy die één mens deur wie die sonde in die wêreld gekom het en deur die sonde die dood, 
en so het die dood tot alle mense deurgedring, omdat almal gesondig het. Dit is 'Adam' as opskrif bokant alle en elke menslike bestaan, as verteenwoordiger en reël waaronder alle mense staan. Ook Paulus ken en respekteer hierdie opskrif. God het dit bokant die wêreldgeskiedenis gestel. Waarvandaan het hy hierdie waarheid gevind of is hy daardeur gevind? Sonder twyfel van die getuienis in Genesis 3. Die vraag is hoe hierdie gedeelte vir hom gesaghebbende Woord van God kon word om die mensheid en wêreldgeskiedenis te verstaan. Hy het in daardie eerste en eensame mens wat direk deur God geskep is en bestaan, in daardie groot kenmerkende sondaar en skuldenaar aan die hoof van die ganse mensheid, daardie duistere verteenwoordiger van almal wat sy naam na hom sal dra - hy het in hom meteens 'n heeltemal ander Een herken. Ook Hy het direk van God gekom, maar nie net as skepsel van God nie, maar as Seun van God, self ook God. Ook Hy is verteenwoordiger van al daardie ander, behalwe dat $\mathrm{Hy}$ nie aan hulle gelyk is nie, dat $\mathrm{Hy}$ nie eerste onder gelykes is nie wat in dieselfde ry staan nie, maar Hy het as leier voor hulle gaan staan en versoenend in Sy gehoorsaamheid hulle sonde van ongehoorsaamheid bedek en hulle voor God geregverdig: 'Soos een oortreding gelei het tot veroordeling van alle mense, so het een daad van gehoorsaamheid dus ook gelei tot vryspraak en lewe vir almal. Soos baie deur die ongehoorsaamheid van een mens sondaars geword het, so ook sal baie deur die gehoorsaamheid van die een Mens vrygespreek word'.

In verband met hierdie uitspraak van die apostel wat die verhouding tussen Adam en Christus betref, word daar gepraat van die Adam-Christus-parallel. Miskien moet daar 'n keer gepraat word van die Christus-Adam-parallel. Daar kan tog geen twyfel oor bestaan nie dat vir Paulus, Christus as oerbeeld, die eerste plek moet kry en Adam, as tipe of model van die Een wat sou kom, (14) die tweede plek. Adam is die voorlopige skadubeeld van Jesus Christus. Hy het Jesus Christus eerste gesien en dan vir Adam. Dit beteken dat hy in Adam, soos in ' $n$ foto-negatief, Jesus herken het. In die onregverdige aan die hoof van die ou mensheid het hy die Regverdige herken aan die hoof van die nuwe mensheid. Juis daardeur word die gedagte van 'n parallel hier problematies.

Die lyn van Adam met al die baie mense wat onder sy ongehoorsaamheid ingesluit is, loop nie selfstandig langs die lyn van Christus in Wie se gehoorsaamheid God Hom oor baie wou erbarm en erbarm het nie. Formeel, wat uiterlike vorm betref, kan die lyn van Adam met die van Christus vergelyk word, maar wat die wesenlike saak betref is hulle onvergelykbaar. Dis hiermee soos 'n reënboog in vergelyking met die son: die reënboog, Adam se lyn, is net 'n terugkaatsing van die son, die lyn van Christus, en daarsonder het dit geen bestendige duur nie. In 
volledige ongelykheid, nie in ewewig, staan die oortreding van die mens in die daad van Adam hier teenoor die genade, die vrye geskenk van vryspraak en lewe in die persoon van Christus daar, en so ook die lot en bestemming van alle mense hier en hulle bestemming en lot daar. Hier moet 'n mens dink aan die woorde van die profeet: 'Net 'n oomblik het Ek jou verstoot, in my groot liefde vat $\mathrm{Ek}$ jou terug. In 'n opwelling van toorn wou $\mathrm{Ek}$ 'n kort tydjie met jou niks te doen hê nie, maar Ek ontferm My oor jou met 'n liefde wat nooit vergaan nie, sê die Here, jou Verlosser' (Jes 54:7; vgl ook Ps 30:5, 12).

Dis tog duidelik wie en wat die eerste en wie en wat die tweede is. Ook as Jesus Christus in 1 Kor 15:45 die laaste Adam genoem word, beteken dit nie dat $\mathrm{Hy}$ in verhouding tot die eerste Adam van Genesis 3, die tweede, maar dat $\mathrm{Hy}$ self die eintlike en eerste Adam, die mens is wat die eerste Adam net as voorafbeelding kon aantoon. Daarvandaan, in 'n terugskou van Jesus Christus af, die laas-te Adam, het daardie eerste een vir Paulus bestaan en vastigheid. Paulus hoor in wat van daardie eerste Adam gesê is, dit wat vir homself en alle mense gegeld het en moes geld: anderkant die drumpel wat Jesus Christus en in en met Hom elke mens intussen oor gestap het, hoor hy in Hom sy vonnis en die van alle mense as God se Woord, die vonnis oor die mens-van-sonde waarteen geen hoër beroep moontlik is nie. Dis die mens wat elke mens was en wat nie een meer is nie, nadat God Hom met dieselfde omvattende genade ontferm het oor almal wat $\mathrm{Hy}$ tevore onder die ongehoorsaamheid ingesluit het in Sy oordeel.

\section{Literatuurverwysings}

Barth, K 1947. Der Römerbrief. Zürich: Evangelischer Verlag.

— 1953. Kirchliche Dogmatik. Vol IV/1(60). Evangelischer Verlag: Zürich.

Noordmans, O 1939. Geestelyke Perspectieven. Amsterdam: H J Paris.

Volkmann, B 1990. Wo ist Wahrheit. Neuhaus-Stuttgart: Hänssler. 